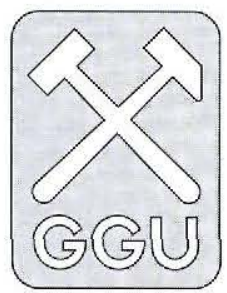

\title{
Archaean and early Proterozoic basement provinces in Greenland
}

Information about the age and plate-tectonic setting of Precambrian basement terrains is of major importance for the evaluation of their mineral potential. The Geological Survey of Greenland (GGU) has therefore over the last two decades collected and published geochronological information on Greenland basement areas, based on wholerock $\mathrm{Rb}-\mathrm{Sr}, \mathrm{Pb}-\mathrm{Pb}, \mathrm{Sm}-\mathrm{Nd}$ and zircon U-Pb isotope data. These isotope data, together with other geochemical information, also yield important clues for the plate-tectonic setting of the investigated terrains. GGU does not have laboratory facilities for isotope work, and most studies were therefore carried out in cooperation with university scientists from Denmark and abroad. This effort has led to the recognition of a number of distinct Precambrian basement provinces. A broad outline of results is given below.

No references are given in this note. The reader is referred to papers by the author in the list of publications of the Geological Survey of Greenland at the end of this Report of Activities and papers cited therein.

\section{Types of basement provinces}

Large sections of the ice-free area of Greenland consist of Precambrian basement rocks - mainly orthogneisses with units of supracrustal origin. Most of these belong to three distinct types of basement provinces: (1) Preserved Archaean terrains (mainly $3000-2600 \mathrm{Ma}$ ), hardly or not affected by later orogenic activity; (2) Archacan terrains reworked during the early Proterozoic (around $1850 \mathrm{Ma}$ ago); and (3) terrains newly formed during the early Proterozoic (2000-1750 Ma; Fig. 1). The latter two are commonly associated with high grade early Proterozoic supracrustal sequences. Unfortunately, most basement gneisses are lithologically uncharacteristic, and in many cases chronological subdivision is only possible with the help of isotope data.

Younger Precambrian rocks occur locally, for example in the 1300-1100 Ma Gardar Province of South Greenland. Rocks of this age are much less common in Greenland than Archaean and early Proterozoic formations, and fall outside the scope of this note.

\author{
Feiko Kalsbeek
}

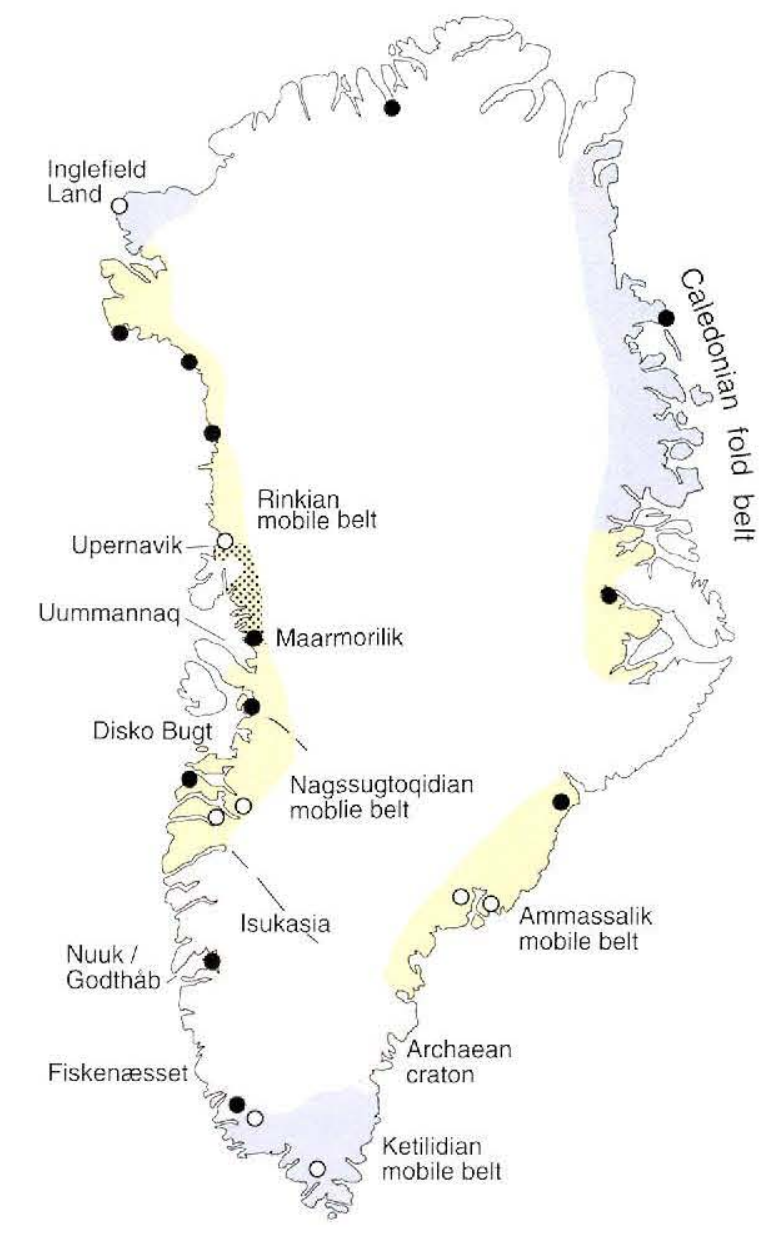

Fig. 1. Simplified map showing the distribution of Archaean and early Proterozoic basement provinces in Greenland. Pink: preserved Archaean (southern Greenland). Orange: Archaean rocks reworked during the early Proterozoic, mainly in the Nagssugtoqidian, Rinkian and Ammassalik mobile belts (early Prolerozoic metasediments in the area north-east of Uummannaq are dotted). Blue: newly formed early Proterozoic rocks. White: younger formations. Filled and open circles schematically indicate localities where the presence of, respectively, Archaean and early Proterozoic rocks has been documented in poorly known areas, and in cases where these ages are in contrast to the age of the surrounding rocks. 

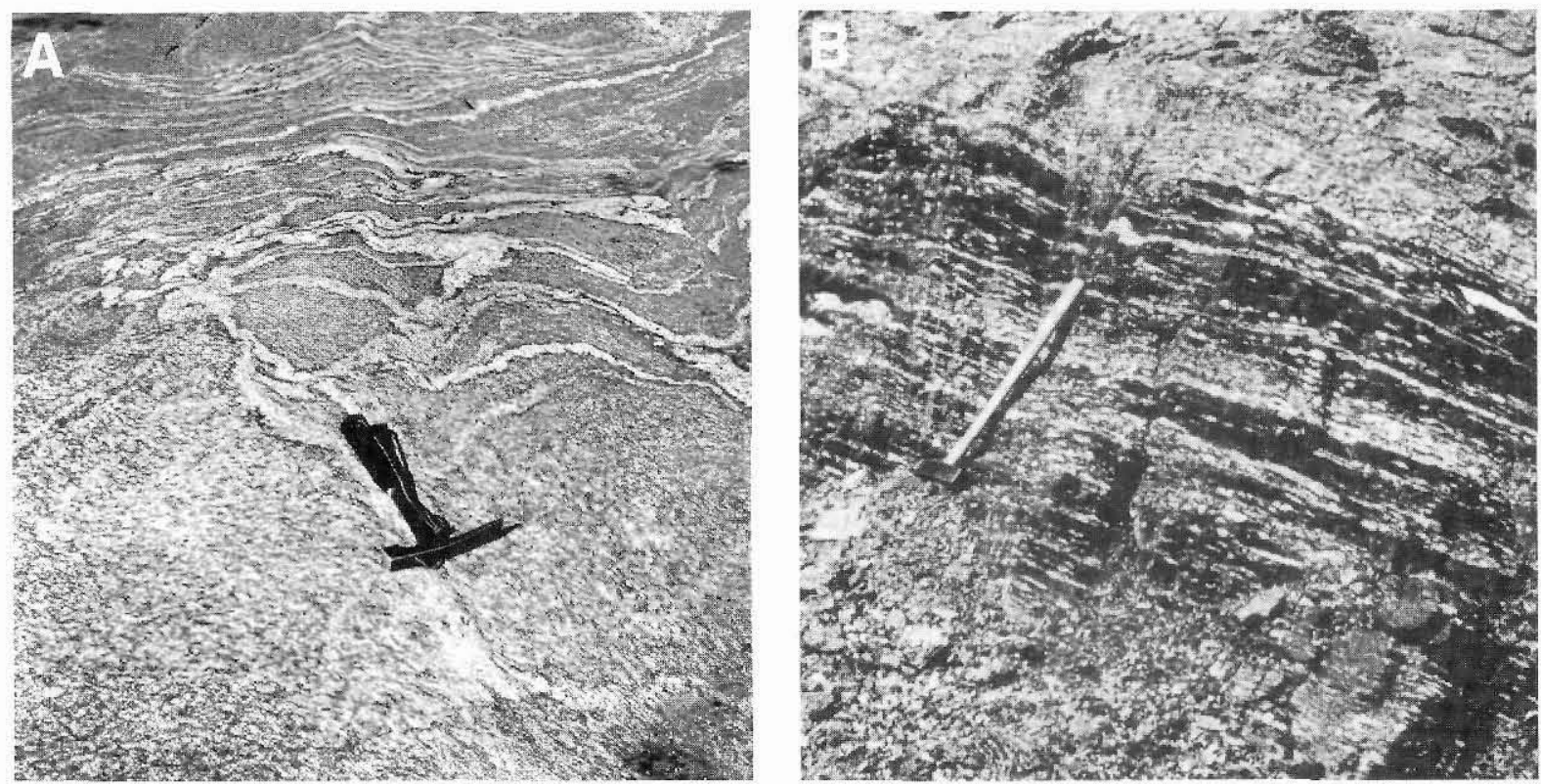

Fig. 2. (A) Archaean orthogneiss, Fiskenæsset area, South-West Greenland. The igneous parent of the gneiss can be recognised in the lower part of the photograph. Photo: J. S. Myers. (B) Chromite (black) with plagioclase occurring as layers in an Archaean anorthosite complex near Fiskenasset, South-West Greenland. Photo: M. Ghisler.

\section{Preserved Archaean terrains}

The only area in Greenland where preserved Archaean rocks occur in abundance is the Archaean craton of southern Greenland (Fig. 1). This region is mainly composed of grey orthogneisses of tonalitic to granodioritic composition (Fig. 2A), most of which were generated 3000-2600 Ma ago. In the Godthăbsfjord area older rocks, $3900-3600 \mathrm{Ma}$, are also present. At many localities the Archaean gneisses are cut by non-deformed and non-metamorphosed basic dykes which have yielded ages of $c .2150$ and $c .1950 \mathrm{Ma}$. Apparently the gneisses were not reworked during early Proterozoic orogenic activity around $1850 \mathrm{Ma}$ ago.

Within the Archaean craton anorthositic rocks are common. In the Fiskenæsset area they are associated with low grade chromite deposits (Fig. 2B). Anorthositic rocks of this type are not known from younger basement areas.

Archaean supracrustal units are mainly composed of metavolcanic rocks of basaltic composition, sometimes with well preserved pillow structures. Nearly everywhere they are at high metamorphic grade, amphibolite to granulite facies. Locally, for example in the Disko Bugt area of West Greenland (Fig. 1), better preserved, lower grade, greenstone belts occur of the type that characterise parts of the Canadian shield. These are not common in Greenland, however. Disseminated scheelite is of fairly common occurrence in high-grade metavolcanic rocks, and gold mineralisation has been reported from several late Archaean greenstone belts. Banded iron formation has been reported from several localities, the largest of these occurrences being the $3800 \mathrm{Ma}$ Isua iron deposit at Isukasia (Fig. 1).

Although there is a general prejudice among Precambrian geologists (including the author) that some kind of plate tectonic processes were active during the Archaean, the true nature of these processes is as yet not well understood. Some 60-85 per cent of the Greenland shield (and a similar proportion of Precambrian crust on a global scale) was generated during the late Archaean, within a time span of a few hundred million years. There are no Phanerozoic equivalents of such a rapid rate of crust formation.

\section{Reworked Archaean rocks and early Proterozoic supracrustal units}

Large parts of the Greenland shield are underlain by Archaean rocks that underwent strong deformation and metamorphism during early Proterozoic ('Hudsonian') orogenic events around $1850 \mathrm{Ma}$ ago (Fig. 1). Isotopic age determination of these rocks is difficult because of major disturbance of the Archaean isotope relationships during Proterozoic reworking. In central West and North-West Greenland well preserved basic dykes, emplaced at $c$. $1650 \mathrm{Ma}$, indicate that Proterozoic orogenic activity had ceased by that time.

Within the Rinkian mobile belt of central West Greenland north of Uummannaq (Fig. 1) reworked Archaean gneisses are overlain by a several kilometres thick succession of early Proterozoic sediments: marble, metapelite 


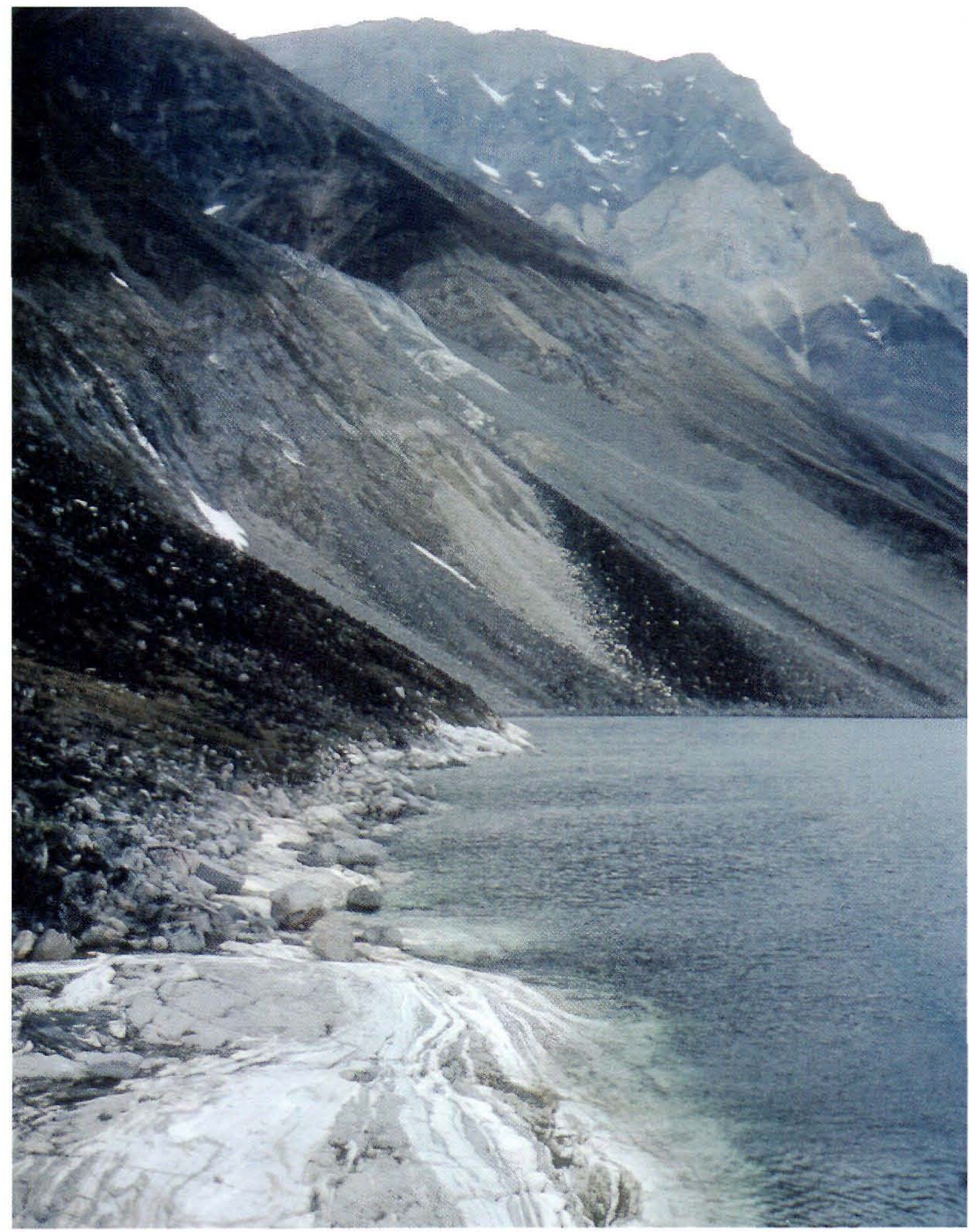

Fig. 3. Early Proterozoic marbles at Appat in the Uummannay area. Marbles with calc-silicates exposed at the coast can be followed on the mountain slopes in the background; here they are in tectonic contact with Archacan gneisses. Such marbles hosted the lead-zinc mine at Maarmorilik. Photo: A. A. Garde. 
and metagreywackes (Fig. 3). Elsewhere, for example in the Nagssugtoqidian belt of West Greenland and the Ammassalik belt of southern East Greenland, such rocks are tectonically interleaved with reworked Arehaean gneisses. The age of deposition of these metasediments is not well constrained.

Archaean gneisses in these terrains have, in principle, the same mineral potential as those in the Archaean craton further south. The same kind of anorthositic rocks occur locally, and banded iron formation has been noted at a number of localities. Early Proterozoic marbles (Fig. 3) may contain massive lead-zinc mineralisation (e.g. the now worked-out Black Angel mine at Maarmorilik, Fig. 1). Early Proterozoic metapelites contain small graphite deposits. Sediments of this kind do not occur within the Archaean craton.

\section{Newly formed early Proterozoic terrains}

The Ketilidian mobile belt of South Greenland (Fig. 1) is mainly composed of granitoid rocks generated 1850 $1750 \mathrm{Ma}$ ago during an early Proterozoic crust forming event. Until recently it was believed that this was the only juvenile early Proterozoic part of the Greenland shield. However, it has now been established that newly formed early Proterozoic rocks are more common. Minor occurrences of juvenile Proterozoic rocks of calc-alkaline affinity have been located in the Nagssugtoqidian and Ammassalik belts (Fig. 1). Furthermore, gneissic basement rocks in Inglefield Land in North-West Greenland, as well as large parts of the crystalline basement of the Caledonian fold belt of North-East Greenland were newly formed during the early Proterozoic. Documentation of the age relationships in these areas is, however, as yet fragmentary. From the crystalline basement of Inglefield Land little information is available, and the early Proterozoic rocks of NorthEast Greenland have been reworked during Caledonian orogenic activity to such an extent that isotopic relationships may be difficult to interpret.

Stratiform occurrences of disseminated uraninite as well as low grade deposits of graphite are present in early Proterozoic supracrustal rocks in the southern part of the Ketilidian belt. In the same area gold-bearing quartz veins have been found within metavolcanic rocks. Mineral deposits with economical potential have not yet been described from Inglefield Land or the early Proterozoic basement of the Caledonian fold belt in North-East Greenland.

\section{Plate tectonic setting of early Proterozoic provinces}

$\mathrm{Sm}-\mathrm{Nd}, \mathrm{Pb}-\mathrm{Pb}$ and $\mathrm{Rb}-\mathrm{Sr}$ isotope data give information on the plate tectonic setting of Precambrian basement rocks, because they permit an estimate to be made of the extent to which older crust has been involved in the petrogenesis of younger rocks. A few examples are given below:

Early Proterozoic granitoid rocks in the Ketilidian belt of South Greenland consist almost entirely $(>90 \%)$ of new mantle derived material. Apparently these rocks were formed at a considerable distance from the Archaean craton. Only in Ketilidian granites in the border zone of the craton can the presence of major components of Archaean crustal material be demonstrated. Accordingly it is believed that the Ketilidian belt, although of great complexity in detail, in outline can be regarded as an accretionary 'Andean type' orogen.

Early Proterozoic rocks in the Nagssugtoqidian belt occur as strongly deformed lensoid units surrounded by Archaean gneisses. Surprisingly, they only contain small proportions of material derived from Archaean crustal material. Isotopically they are reminiscent of the granites (sensu lato) of the central part of the Ketilidian belt, and not those in the southern border zone of the Archaean craton. This suggests that early Proterozoic granitoid rocks in the Nagssugtoqidian belt formed at a considerable distance from Archaean continents, perhaps in an island arc setting. It is believed that these rocks were caught between two Archaean continents during collision some $1850 \mathrm{Ma}$ ago. Accordingly, the Nagssugtoqidian belt is interpreted as a collisional 'Alpine type' orogen. Indeed, the occurrence of high grade metamorphic rocks and 'syn-collision' granites in the centre of the belt support this interpretation.

Early Proterozoic granites (sensu lato) in the basement of the Caledonian fold belt of North-East Greenland often contain a very significant component derived from Archaean crust. Isotopically these rocks are reminiscent of Ketilidian granites in the border zone of the Archaean craton rather than granitoid rocks in the centre of the Ketilidian belt. Trace element data suggest that early granitoid rocks were formed during subduction of early Proterozoic ocean floor beneath an Archaean continental block. Later potassic granites may have formed during continental collision. Apparently, this belt of early Proterozoic rocks represents a collisional orogen formed close to the border of an Archaean craton.

Further studies aimed at understanding plate-tectonic processes in Precambrian terrains of Greenland have been planned in co-operation with the Danish Lithosphere Centre funded by the Danish National Resarch Foundation.

\section{F. K., Geological Survey of Greenland, Copenhagen}

